\title{
Lumen
}

Selected Proceedings from the Canadian Society for Eighteenth-Century Studies

\section{A Crafted Debut: Haywood's Love in Excess and the Literary Marketplace}

\section{Holly Luhning}

Volume 28, 2009

URI : https://id.erudit.org/iderudit/1012040ar

DOI : https://doi.org/10.7202/1012040ar

Aller au sommaire du numéro

Éditeur(s)

Canadian Society for Eighteenth-Century Studies / Société canadienne d'étude du dix-huitième siècle

ISSN

1209-3696 (imprimé)

1927-8284 (numérique)

Découvrir la revue

Citer cet article

Luhning, H. (2009). A Crafted Debut: Haywood's Love in Excess and the Literary Marketplace. Lumen, 28, 97-110. https://doi.org/10.7202/1012040ar

Copyright (C Canadian Society for Eighteenth-Century Studies / Sociéte canadienne d'étude du dix-huitième siècle, 2009
Ce document est protégé par la loi sur le droit d'auteur. L'utilisation des services d'Érudit (y compris la reproduction) est assujettie à sa politique d'utilisation que vous pouvez consulter en ligne.

https://apropos.erudit.org/fr/usagers/politique-dutilisation/ 


\section{6: A Crafted Debut: Haywood's Love in Excess and the Literary Marketplace}

Eliza Haywood's literary debut, Love in Excess (1719), gained a wide readership, was a commercial success, and established Haywood's notorious yet profitable reputation as a scandalous woman novelist. In 1747 John Mottley claimed that Haywood was "made eminent" by Love in Excess. ${ }^{1}$ Patrick Spedding notes that the "growth in popularity of Love in Excess is apparent from the [number of editions and copies produced of the] publications themselves" and that Haywood was "commissioned to write a series of novels on the basis of the success of this work." ${ }^{2}$ This success and popularity did not come about randomly; William Chetwood, Haywood's publisher, introduced and subsequently marketed Love in Excess to the reading public in a deliberate manner. He used dedications, readers' responses, strategic prefatory material, and special editions not only to promote the sales of Love in Excess, but also to construct a glamorous and risqué authorial persona for Haywood that subsequently characterized her writing. Through this commodification of her writing and persona Haywood publicized the authenticity and cultural relevance of her work. Her successful participation in the literary marketplace was instrumental in achieving a wide readership not only for herself, but also for other women novelists.

The first part ${ }^{3}$ of the first edition of Love in Excess does not directly credit Haywood as author; her name first appeared on the second part

1 John Motley, "A Complete List of All the English Dramatic Poets," in Scanderbeg, or Love and Liberty. A Tragedy, ed. Thomas Whincop (London: W. Reeve, 1747), 246.

2 Patrick Spedding, A Bibliography of Eliza Haywood (London: Pickering and Chatto, 2003), 88.

3 Love in Excess was published in separate parts; the first part "was issued anonymously but subsequent parts, and later editions of the first part, have Haywood's name on them" (Spedding 90). 
of the first edition. Instead of placing Haywood's name on the book, Chetwood prefaced the first part with a letter of dedication to the celebrated actress, Anne Oldfield. Though he never mentions Haywood's name, this letter serves to introduce the new young author not only to Oldfield, but also to the general reading public. Chetwood links the unnamed author's aesthetic tastes to her appreciation of Oldfield's art. He writes:

The Author of the following Lines is a young Lady, whose greatest Prise is in the Patroness I have chose her; but she's fearful in not pleasing one who I am well assur'd is a real critik without their ill nature. ${ }^{4}$

Chetwood appeals to Oldfield's fans by establishing Haywood as one of them and by praising Oldfield's intelligence, critical sensibility, and general kindness. Later in the letter, Chetwood further identifies Oldfield as a desired and desirable reader. He positions Haywood's texts as potentially worthy of Oldfield's attention and capable of giving Oldfield joy; he writes, "I shall think my self very Happy if I cou'd have it to say the reading these following Lines had fill'd up the Casmer of one of your vacant Hours. ${ }^{\prime 5}$ If Oldfield, with her busy, glamorous life, were to take the time to read this text, her act of reading would signal to the public that the work is one to which they should pay attention.

The connection between Oldfield and Haywood is significant because of the commonalities that would emerge between the two women's careers, and what these commonalities reveal about the cultural significance of both women's work. Oldfield, like Haywood, was very productive; between " 1715 and 1730 , she appeared in no fewer than twenty-three new plays" and during her thirty-year career she appeared in "over one hundred roles, of which nearly seventy were original." ${ }^{6}$ Around the time of publication of the first edition of Love in Excess, Oldfield's career had hit a high point; in 1718 she "created one of the great sensations of her career in the role of Cleopatra," and Richard Savage wrote an "ecstatic poem about Oldfield's performance," just

4 William Chetwood, "To Mrs. Anne Oldfield," in Love in Excess by E. Haywood, first edition, first part (London: W. Chetwood, 1719), ii.

5 Ibid., ii.

6 Joanne Lafler, The Celebrated Mrs. Oldfield: the life and art of an Augustan actress (Carbondale and Edwardsville, Illinois: University of Southern Illinois Press, 1989), 135,3 .

7 Ibid., 5. 
as he would write a similarly-toned piece to honour Haywood's first novel. Oldfield, much like Haywood, did not publicly speak of or record much of her personal life; however, critic Joanne Lafler speculates that Oldfield, like Haywood, consciously cultivated a sense of mystery, and that Oldfield

herself contributed to the process of mythmaking, for she was undoubtedly the source of stories about her mother's genteel origins, her father's commission in the Horse Guards, her stagestruck childhood, and her fairy-tale discovery by George Farquhar. At the same time, either by omission or design, she left behind not a single letter, not even a hastily scribbled note, that might reveal her motives or feelings. ${ }^{8}$

This mystique contributed to the popularity and the longevity of her career. Like Oldfield, Haywood hinted in her dedications that she had an unfortunate marriage and had previously worked as an actress, but she left behind no diaries, revealing personal letters, or autobiography. There is no official or reliable record of her origins or the events of her life. Both women presented an economically effective persona in their business and artistic affairs.

Interestingly, both Haywood and Oldfield suffered backlash from similar sources. Pope, who ridiculed Haywood in The Dunciad, also aimed harsh words at Oldfield. After her death Pope references her in "Epistle 1" of his Moral Essays:

"Odious! In woolen! 't would a Saint provoke,"

(Were the last words that poor Narcissa spoke)

"No, let a charming Chintz, and Brussels lace

Wrap my cold limbs, and shade my lifeless face:

One would not, sure be frightful when one's dead -

And - Betty - give this Cheek a little Red.'

Oldfield was well-known for playing Narcissa and several other similarly-disposed characters; although Pope's words are cruel, they speak to Oldfield's fame and success on the stage. Similarly, Haywood's persona also suffered attacks from Pope. Oldfield's and Haywood's personae were female, feminine, and public. This combination worked on one hand to promote their work and themselves as novel, interest-

8 Ibid., 3.

9 Alexander Pope, "Epistle 1," Moral Essays, lines 246-51. 
ing, and scandalous, but functioned on the other hand to leave them open to negative remarks based on their participation as women in the public sphere.

\section{Prefatory Poems}

In addition to the dedication to Oldfield, Love in Excess was printed with several prefatory poems that worked to flatter the text and the author. The part of the first edition of Love in Excess, with the dedication to Oldfield, sold very well; Chetwood followed up this success by publishing the subsequent parts and further editions under Haywood's name. Laudatory prefatory poems were common and Chetwood strove to reinforce and heighten public interest in Haywood by including several poems dedicated to her in the preface material to her debut novel. The first poem Chetwood included is a piece written by Richard Savage; the poem was first published with the second half of the first edition and was included in all subsequent editions. The poem, titled "To Mrs. Eliza Haywood, on her Novel, call'd Love in Excess \&c," praises both Haywood's talent and her text. Savage rates Haywood's talent as above his own and compliments her narrative skill, noting especially the characterization of D'Elmont and Melliora. Savage endorses Haywood's literary skill and describes her talents as being powerful enough to rival Apollo's "fierce Beams." ${ }^{10}$ Raymond Anselment notes that in the eighteenth century "although Phoebus Apollo, the god of poetry and music, would in time be less significant as a god of healing, he remained... a physician of the body and the soul. ${ }^{11}$ Haywood's writing illustrates the power of physical and emotional love and its effects on the mind and body. Savage also connects this insight to the power of the masculine sun, implying that her work will "luminate" their times. His poem identifies both Haywood and the novel as extraordinary.

By at least the fourth edition of Love in Excess another poem appears alongside Savage's piece, which also compares Haywood's skill to that of Apollo and promotes both Haywood and the text. The author comments on how he has gained a more positive perspective of both love

10 Richard Savage, "To Mrs. Eliza Haywood, on her Novel, call'd Love in Excess \&c" Preface to Love in Excess by E. Haywood, first edition, second part, (London: W. Chetwood, 1720), line 23.

11 Raymond A. Anselment, The Realms of Apollo: Literature and Healing in SeventeenthCentury England (London: Associated University Presses, 1995), 23. 
and women than he had before reading Haywood's work. The poem, titled "By an unknown Hand. To the most Ingenious Mrs. Haywood, on her Novel entitled Love in Excess," not only attributes to Haywood's text the power to turn the speaker from atheist to believer with regard to love, but also figures Haywood as an inspirer of desire because of her abilities as an author; her writing has the power of Cupid's dart. Like Savage, the speaker connects Haywood to Phoebus Apollo and the sun:

No more of Phoebus, rising vainly boast

Ye tawny sons of a luxuriant Coast!

While our blest Isle is with such Rays replete

Britain shall glow with more than Eastern Heat! ${ }^{12}$

In these lines the speaker rejects foreign symbols such as "tawny sons" of a stereotyped "luxuriant" Asian land. The suggestion that Haywood's "Rays" are stronger than "Eastern" heat and as such will warm Britain implies that her writing is not only skilful, but will also have an impact on a national scale. Apollo is a powerful god; however, the speaker of the poem ranks Haywood's skills as even more powerful than Apollo's. Haywood's persona is tied to or perhaps even defined by her sizable literary talent, and this talent is poised to affect positively a reading nation.

Savage's poem, much like the Oldfield dedication, promotes Haywood's text and builds her persona by connecting her with another famous yet controversial figure. Clarence Tracy notes that Savage, who "knew everybody and in one lifetime experienced nearly every way of life open to a man of his time,"

was taken up as a fad in fashionable circles and caressed by exaulted personages; he was pitied and mothered in his misfortunes by frustrated women; he was saved from the gallows by the queen; he was execrated by members of the literary rabble for his lack of respect for themselves; he was supported financially by several of the most responsible men in England. ${ }^{13}$

12 Anonymous, "By an Unknown Hand, To the most Ingenious Mrs. Haywood, on Her Novel Entitled Love in Excess," Preface to Love in Excess by E. Haywood. First edition, second part, second issue, (London: D. Brown, 1720), viii.

13 Clarence Tracy, The Artificial Bastard: A Biography of Richard Savage (Toronto: University of Toronto Press, 1953), vii. 
Like Oldfield, Savage was not unconnected with scandal. He publicly maintained that he was the cast-off, illegitimate son of Countess Macclesfield and the Earl Rivers, and although his satirical and dramatic works were somewhat successful, according to Samuel Johnson's biography, he largely relied on literary friends and patrons for support. ${ }^{14}$ Johnson notes that his dedications were almost embarrassingly effusive; he writes that Savage "seems to have written his panegyrics for the perusal only of his patrons, and to have imagined that he had no other task than to pamper them with praises however gross, and that flattery would make its way to the heart." ${ }^{15}$ Although by 1719 Savage had not yet been accused of murder (this would happen in 1727), he was already publicly perceived as a controversial but interesting figure. Savage's poem would likely have indicated that Haywood and her work were sufficiently fashionable, interesting, and influential for Savage to desire to connect his name with hers. Tracy posits that Savage and Haywood met after the first edition of Love in Excess was published because "a complimentary poem would normally be printed in the first volume." ${ }^{16}$ Perhaps the chronology of this assumption is accurate (although Savage's poem did appear in the first edition, just the second part of it), but Chetwood's dedication to Oldfield appears very deliberate. If Chetwood had clearly identified Haywood in the first part of the first edition, or indicated that she was connected with Savage or Aaron Hill's circle, he would not have created the mystique that he achieved by "discovering" and introducing an unknown writer. ${ }^{17}$ Also, the appearance of Savage's poem in the second part creates the perception that Savage, a man who worked to connect himself with many influential people, was interested in associating himself with Haywood. Further, the subsequent poems by anonymous and established writers emphasize to readers that Haywood was gaining popularity, and that her writing was being discovered and enjoyed by not only a general readership, but also by her peers; Chetwood and Haywood orchestrated a buzz around Haywood the author.

14 Samuel Johnson, Life of Savage, ed. Clarence Tracy (Oxford: Clarendon Press, 1971), 16.

15 Ibid., 17.

16 Tracy, Artificial Bastard, 60.

17 See Christine Gerrard's Aaron Hill, The Muses' Projector, 1685-1750 (Oxford: Oxford University Press, 2003). 
However, some early twentieth-century critics have used the link between Haywood and Savage as a basis for negative speculations about Haywood the woman, and have subsequently disregarded her writing, or have considered it only as a potential source of gossip about her life. For example, George Whicher minimizes the literary worth of Haywood's writing, and Clarence Tracy seems interested in Haywood only because of her connection to Savage. Tracy claims that "[t]he first member of Hill's group whom Savage met was Mrs. Haywood." ${ }^{18}$ Tracy, however is not a fan of Haywood's writing; he reports that "she tried to support herself by writing, turning out several plays and a string of novels unequalled in literature for the dreary monotony of their seduction scenes." ${ }^{19}$ Tracy also cites Haywood's Memoirs of a Certain Island Adjacent to the Kingdom of Utopia (1724) as evidence that Haywood and Savage were on intimate terms; he refers to this work of fiction as "testimony" about Savage's life and childhood. He reads the novel as a roman à clef. He believes that the text is proof that Haywood and Savage were at one time intimate, that Savage was the father of Haywood's eldest child, and that another woman in Hill's circle, Martha Fowke Sansom, came between them. Tracy goes as far as to assert (without any discernable evidence) that "[b]etween these two frantic females Savage steered his course with little regard to the feelings of either." ${ }^{20}$ In his bibliography, Spedding corroborates that Memoirs has characters based in part on Savage and Sansom, and concedes that since "Haywood's first child was clearly conceived and born c. 1722-23, when Savage and Haywood were on friendly terms[,]...there is good reason to consider Savage as the father of Haywood's eldest child" but he cautions that

while this explanation is attractive, it must be remembered that nowhere in the mass of biographical material concerning Savage, positive and negative, is there any mention of the 'bastard's bastard', something, one would imagine, too piquant to be passed over in silence. ${ }^{21}$

While, at present, there is no firm evidence to support the suggestion that Savage fathered one of Haywood's children, Savage's poem praising Love in Excess, as well as a second he wrote that prefaced the 1724

18 Tracy, Artificial Bastard, 60.

19 Ibid.

20 Ibid., 64.

21 Spedding, 208. 
edition of The Rash Resolve, demonstrates at least a professional link between Haywood and himself. Moreover, the poems suggest that both Haywood and her work were popular within London's literary circle; Savage had as much to gain from his association with the popular Haywood as she had from publicizing his praise of her work. Tracy interprets the appearance of Savage's poems together with Haywood's authorial persona, as a representation of a lurid writer and a lurid woman. He defines Haywood through her relationships with Savage and Sansom and her status as an unwed mother. As a consequence he dismisses her work. For Tracy, Savage's poem simultaneously draws attention to and disparages Haywood's writing and persona.

Savage's poem was not the only laudatory material included in Love in Excess: the second to sixth editions contained two to three other poems, suggesting that such prefatory material was effective at marketing both the novel and author. The novel was reprinted for six editions from 1719 to $1742:^{22}$ each new edition included one or both of the original two flattering poems, and sometimes a third, anonymous poem ${ }^{23}$ entitled "Verses wrote in The Blank Leaf of Mrs. Haywood's Novel."24 This piece refers to Haywood's characterization of Count D'Elmont. The speaker reinforces D'Elmont's attractiveness, and credits "love" for reforming him from a rake into "manly" hero who becomes a generous lover. This transformation marks an alteration in D'Elmont's motivations regarding courtship and ultimately allows for D'Elmont to treat Melliora in a loving, respectful way that leads to their socially sanctioned union, and her subsequent happiness. This poem indicates the popularity of D'Elmont as a hero, and of readers' positive reception of

22 There is controversy over the number of editions of Love in Excess. According to Spedding, Chetwood misrepresented "reissues as new editions and seems to have had no scruples about skipping 'editions' altogether" (88). According to Spedding's research, the first edition of LIE was issued twice, but Chetwood advertised the second issue as the third edition. He referred to the second printing as the fourth edition. (Spedding has since renumbered the editions in his bibliography so that reissues are not counted as editions.) However, other critics such as Christine Blouch believe there could be eight or more editions of LIE. The controversy over the number of editions leads to some confusion with regard to how well LIE actually sold; Spedding's recent bibliographic work concludes that 6000 copies of the novel were printed "over a 23-year period" (88).

23 I have consulted ECCO, the Bodleian Library, the British Library, and the Chawton House Library, and I have viewed the first, fourth, fifth, and sixth editions. However, if Spedding's suggestions about the skipped editions and reissues are correct, I have viewed the total four distinct editions, if not all of the reissues.

24 This poem first appears in the fourth edition. 
D'Elmont as a reformed, sensitive man. The title of the poem gives the impression that the author was moved to express his or her feelings in verse directly after reading the novel, this act, whether it is true or a fabrication for publicity, suggests the story elicits a strong emotional response from readers.

The sixth edition of Love in Excess, printed in 1725 and by Dan Brown $^{25}$ instead of Chetwood ${ }^{26}$, is prefaced by a poem by James Sterling, a young Irish poet who had at the time recently moved to London; the poem, included six years after the book's initial publication, and the high quality of this edition, suggest that Love in Excess retained a high level of popularity. On this edition's colourful title page, Haywood's name appears in red, in contrast with the black ink of the rest of the front matter. The extra cost and labour associated with a multicolour title page suggests that in 1725 Haywood's popularity and readership were significant; an expensive version could indicate that an affluent or higher-class readership was interested in her work, and that these buyers were interested in owning aesthetically-pleasing productions of Love in Excess to display in their libraries. Sterling's poem, "To Mrs. Eliza Haywood, On Her Writings," praises Haywood's body of work, not just Love in Excess; the poet's youth (he was born in 1701) implies that Haywood had established a positive reputation with not only an affluent class who could afford expensive editions of her work, but also by a younger generation. Whether or not Sterling's poem was voluntary or commissioned, its inclusion produces the impression that the novel elicited the verse from this young poet. Sterling's occupation as poet also suggests that Haywood was esteemed by emerging young writers, or at least, considered to be an advantageous figure to whom

25 Sarah Prescott suggests that Chetwood collaborated with Brown (and Brown's occasional partner Chapman) on the publication of some of Haywood's early works; both booksellers produced a significant number of her early texts. That Haywood repeatedly worked with certain booksellers "suggests that they found her work profitable and that she was reasonably satisfied with her relationship with them. The fact that she also, at times, moved between different booksellers suggests that Haywood was successful in shopping around for the best deal" (Sarah Prescott, Women, Authorship and Literary Culture, 1690-1740 [New York: Palgrave Macmillan, 2003], 107). Also, this situation indicates that Haywood's work facilitated collaboration between booksellers, and that she was an important nexus in the multi-layered networks of the marketplace.

26 Although Brown published the so-called sixth edition of LIE, Spedding suggests that he was involved with Haywood's work well before this edition appeared (Spedding, 99). 
to link their names. Sterling not only praises Haywood ${ }^{27}$ but also presents the idea that females can display "full Vigour" of spirit and ability. He too describes Haywood as godlike and speaks of her work's ability to affect readers acutely and emotionally. Sterling proposes that the combination of her skill and gender elicits fear from some people who "wish it less refin'd, and nearer Man." ${ }^{28} \mathrm{He}$ also coins the phrase "Great Arbitress of Passion," which contemporary critics such as Ros Ballaster, David Oakleaf, Alexander Pettit, Catherine Ingrassia, and Spedding use to characterize Haywood's persona. Karen Harvey charges that Haywood "famously styled herself the 'Great Arbitress of Passion,'"'29 but in fact it was Sterling who first called her by that term. Unlike Aphra Behn or Delariviére Manley, who employed direct self-promotion of their work, Haywood had other people publicly praise her. Whether these people praised Haywood of their own accord or whether their laudatory comments were commissioned, this external praise created the public impression that Haywood was so talented that other people volunteered to praise her so she did not need to praise herself directly.

The second half of Sterling's poem speaks about the social value of Haywood's subject matter and her cultural position in terms of a tradition of women writers. In this section, Sterling depicts Haywood as possessing great power over her readers, for her work "command[s]" readers' emotions. ${ }^{30}$ Sterling also introduces the issue of gender and social education. He claims that much like the factioin of society that fears the combination of Haywood's gender and genius, the "brutal Force of envious Man" leads to a restriction of women's education. ${ }^{31}$ Further, Sterling ranks Haywood above Behn and Manley in terms of literary accomplishment and asserts that "when Haywood writ, / She clos'd the fair Triumvirate of Wit. ${ }^{\prime \prime 2}$ He notes Haywood's near-satirization of con-

27 In the editions I have studied, Savage's poem comes first from the first to the fourth edition, followed by the two anonymous poems. In the sixth edition, Sterling's poem appears first, and Savage's is bumped down to second place.

28 James Sterling, "To Mrs. Eliza Haywood, On Her Writings," Preface to Love in Excess by E. Haywood, $4^{\text {th }}$ edition (London: D. Brown, 1722), v.

29 Karen Harvey, Reading Sex in the Eighteenth Century: Bodies and Gender in English Erotic Culture (Cambridge: Cambridge University Press, 2004), 31.

30 Sterling, "To Mrs. Eliza Haywood," vi.

31 Ibid.

32 Ibid., 50-51. 
ventional morality in her writing and suggests that, "Born to delight as to reform the Age, / She paints Example thro' the shining Page ${ }^{\prime \prime} .{ }^{33}$ Sterling suggests that her work is destined to reform and improve dominant cultural ideologies. Contemporary critics such as Paula Backscheider have echoed what Sterling observed almost two and a half centuries earlier; she notes that "Haywood seems to have had an ironic self-consciousness about narrative voice that admits near-parody, metacommentary, deconstruction, and ironic double-commentary into her texts. ${ }^{34}$ Haywood's popularity was fueled not only by the construction of her authorial persona but also the texts she wrote. Her prose was entertaining and titillating, but also socially relevant; she questioned the validity of cultural systems, particularly those that sought to marginalize women's social agency and sanitize the complications that often accompany the experience of love within an economically and politically restrictive society.

All of these prefatory verses then work to establish Haywood as a marketable, attractive author and the text as a strong and effective narrative. The second anonymous verse in particular reinforces the idea that readers' perceptions of gender roles and ideal masculinity were notably influenced by Haywood's presentation of the hero, and also that the text affected readers to the extent that they were compelled to record their feelings in verse form, directly and magically in the blank spaces of Haywood's books. Haywood's persona and her texts assumed a viable position in the cycle of cultural production and response.

\section{Handling the Persona}

Although Haywood and Chetwood may have set out to promote Haywood and her texts in one manner, ultimately they could not fully control public reception and responses to the persona and the writing; the perceptions, and hence the personaes became multiple, as did the responses to her work. Chetwood's letter to Oldfield presents Haywood as an ingénue who aims for her work to be enjoyed by the public and by Oldfield specifically. The connection with Oldfield supports Oldfield and the cultural status she stood for: women in the public eye, a life lived on the edge of respectable society, and fame. The poems that preface the various editions of Love in Excess offer more layers, and as-

34 Paula R. Backscheider, "The Story of Eliza Haywood's Novels: Caveats and Questions," in The Passionate Fictions of Eliza Haywood, eds. Kristen T. Saxton and Rebecca P. Bocchicchio (Kentucky: University of Kentucky Press, 2000), 28. 
sociate more identities with Haywood's persona. Savage and another anonymous reader praise Haywood's writing abilities; Haywood becomes not just a hopeful ingénue, but a woman writer of acknowledged skill and talent. This layered persona of a skilled writer addressing the composition of women's characters implies significant social influence: her writing has changed how her readers view women. The reader who writes on Haywood's characterization of D'Elmont adds yet another layer: Haywood is credited with insights into love, men, and masculinity that again are new ideas for the reader. Sterling's poem credits her with the ability to entertain, as well as to engage in serious social discussion. These different characterizations illustrate that Haywood's early persona had many facets, and that her persona(s) and writing influenced readers' thinking about social and cultural issues such as gender roles, courtship, love, and social morality. The commercial success of her work, along with the evidence of positive public responses to her persona and writing, indicate that Haywood achieved significant cultural standing. Whether the responses to her persona(s) and writing were negative or positive, interest in Haywood is consistently linked to her cultural reception and influence. The opposition as well as the adulation that Haywood and her writing garnered indicates that, her work and her public self promoted social discussion.

Haywood achieved significant literary and commercial success very early in her career. She followed Love in Excess with several more commercially successful novels and a collection of her works, The Works of Mrs. Eliza Haywood, was published in 1724. In five years, Haywood moved from being an unknown writer to having a career and texts worthy of publishing a collected works. The creation of The Works so early in Haywood's career can be seen as a powerful move to establish Haywood as a distinguished, influential author; its release signifies that Haywood's writing was both culturally significant and economically viable. Sarah Prescott explains that

The appearance of the collected 'Works' of authors like Aubin, Barker, Davys and Haywood represent an attempt by publishers to claim a higher literary status for the commercial genre of the novel and add a veneer of seriousness to texts which could easily be perceived as ephemeral entertainment. Furthermore, by appearing as authors of a corpus of writing worthy of collection, women could be seen to have canonical standing and literary importance as well as commercial appeal. ${ }^{35}$ 
The occupation of these dual positions upset the literary status quo. A serious writing career often belonged to a man and entailed at least a brief period of obscurity before achieving the type of popularity Haywood gained with her first publication. James Raven points out that "[c]ommodification enraged those who identified literary devaluation and potential social instability as the consequence of increased print production. ${ }^{\prime 36}$ Now, with the presentation of Haywood's work in collected editions, her writing was not just involved in the "problem" of decreasing the status of literature by its plentiful existence; it was simultaneously commercial and literary. Haywood, a woman who emerged from the fray of the new print market, established herself as a genuine, significant author.

Haywood's success was also an example of the intersection of culture and business. Raven remarks that "[c]ulture... need not be commercial, but it often is. Culture, indeed, can be big business." ${ }^{\prime 37}$ Chetwood's risk, publishing an unknown woman writer's first novel, was "amply repaid...as this text not only made Haywood famous, but was also consistently reprinted throughout the eighteenth century." ${ }^{38}$ Spedding accuses Chetwood of inflating the rate of sales for the book by skipping editions and making it look like the book was selling better than it actually was. ${ }^{39}$ But, in an industry where "[n]umbers counted more than prestige, ${ }^{\prime 40}$ it is no surprise that Chetwood would choose to create the illusion of extremely high sales for the text at the expense of accurate record-keeping with regard to issues and editions. The economic success that Haywood's text provided Chetwood influenced the perception of what he and other booksellers considered to be marketable: cultural tastes and economic interests were mutually influential.

Haywood's success proved that women's fiction was marketable. In addition, her incredible speed of composition - on average, she produced a novel every three months - means that her work constituted a large percentage of literature that was being written by women at the time. Her rapid rate of production led her publishers to view her and her work as commercially viable investments. Sarah Prescott posits that "Haywood's success can be said to have changed the face of the

37 Ibid., 2.

38 Prescott, 106.

39 Spedding, 88.

40 Raven, 207. 
marketplace for fiction dramatically. The decade following the publication of Love in Excess saw a remarkable increase in the publication of women's fiction." ${ }^{\prime 1}$ The novelists "high profile presence in the marketplace paved the way for women to be recognized as established authors whose work could be sold on the strength of a name." ${ }^{\prime 2}$ Haywood's work achieved widespread recognition in the marketplace and became an example that women's writing could be a lucrative product.

Love in Excess marked two related and equally important successes for Haywood: the text itself became popular and flourished, and her persona, a vehicle that would become one of her main marketing tools and which would influence the reception of her work and of women writers' work in general, became established. Haywood's work during this period - both literary and commercial - confirmed not only her success as a writer, but also positively influenced the reception of future women writers in the literary marketplace.

HOLLY LUHNING

McGill University 